Mulder, C.H., \& Hooimeijer, P. (1995). Moving into owner-occupation: compositional and contextual effects on the propensity to become a home-owner. Netherlands journal of housing and the built environment., 10(1), 5-25. 


\title{
MOVING INTO OWNER-OCCUPATION: Compositional and contextual effects on the propensity to become a homeowner
}

\author{
Clara H. Mulder and Pieter Hooimeijer
}

\section{Introduction ${ }^{1}$}

The decision to become a first-time home buyer has important implications, both at the level of the household involved, and at the level of the housing market. As the number of first-time buyers is decisive in the development of demand for additions to the owner-occupied stock, short-term fluctuations contribute to the instability of private residential development and long-term fluctuations influence the structural position of this sector in the national economy. At the level of the individual household, the decision to become a homeowner has immediate repercussions on disposable income and long-term implications for the accumulation of assets.

Many factors influence a household's decision to either rent or buy. Individual resources and constraints (life course factors) play a major role, but factors outside the household (context factors) are also important: the availability of housing opportunities, the level of mortgage interest and the willingness of banks to provide mortgage loans are only a few examples. Fluctuations in the number of first-time buyers will therefore be the result of compositional changes in the population with respect to the relevant life course attributes, of contextual changes such as house price inflation, mortgage rent levels and consumer confidence, and of changes in propensity indicating a changing value orientation towards owner-occupation.

The connection of the choice between renting and buying with both life course and context factors has been well documented in the literature. Empirical analyses, however, have predominantly been restricted to either context factors analysing time series, or life course factors analysing micro, sample data. Recently the inclusion of context variables in estimating equations using micro-level data has become more common (Loikkanen, 1992; Haurin et al., 1993; Clark et al., 1994; Deurloo et al., 1994). With the exception of the latter two studies, the time period over which tenure choice is being analysed at the micro level is usually restricted, due to a lack of consistent long-term longitudinal data or repeated cross-sections.

The aim of this article is to assess the influences of context effects on the decision to buy after controlling for compositional effects that arise from the

Neth. J. of Housing and the Built Environment, Vol. 10 (1995) No. 1. 
changing distribution of the population with respect to life course factors. A multivariate analysis is performed, focussing on how the choice to rent or buy is related to a combination of individual characteristics, an indicator denoting the local housing market situation, and an indicator denoting the period of observation. The data are derived from the Housing Demand Surveys conducted in the Netherlands in $1977,1981,1985$ and 1989. The analysis is restricted to respondents aged 18-39 because the vast majority of all changes of residence is undertaken within this age span and the focus is on first-time buying.

A review of existing evidence on the choice between renting and buying a dwelling is given below, leading to hypotheses concerning the outcomes of the empirical analyses. Next, the data and methods used in this article are presented. The results of the multivariate analyses are then discussed. It will be concluded that compositional change (in particular changes in household composition) obscures a consistently growing propensity to move into owner-occupation in the Netherlands, due to contextual effects.

\section{Renting or buying a home: life course and context factors}

Evidently, the choice between renting and buying a home is determined by both individual (or household) and external factors. The choice is made on the basis of individual preferences, mediated by individual resources and constraints, in a context of perceived opportunities and macro constraints.

Individual and household factors are considered from a life course perspective in this article. The life course perspective adequately accounts not only for the dynamic nature of individual characteristics, but also the continuity of people's biographies: their co-ordination of past, present and future behaviour. In employing a life course perspective it is helpful to regard people as following parallel, intertwining careers in different life spheres: a labour market career, a residential career and so on. An individual's complex system of careers is denoted as a life course.

The decision to move and the choice between renting and buying are viewed here as separate decisions. It is assumed that the decision to move is made first (cf. Speare et al., 1975; Onaka and Clark, 1983; Everaers and Dieleman, 1992). The subsequent decision to either rent or buy may arise from factors completely different than those underlying the decision to move. Only the outcome of this second decision is studied here. Consequently, the 'trigger' of the move is ruled out and only the 'conditioning' effects (Mulder, 1993) of parallel careers need consideration. The validity of this assumption might be questioned, as various authors assume joint or hierarchical decision rules with respect to moving and tenure choice (Clark and Onaka, 1985; Rima and Van Wissen, 1987). Some even include decision-making with respect to household formation (Haurin et al., 1993). We will return to this issue when interpreting the results.

There is abundant evidence of a crucial resource effect of income and wealth on tenure choice. The owner-occupied market segment is still hardly accessible to lower-income groups. When they move, the higher-income groups choose to buy 
relatively often (Struyk and Marshall, 1974; Doling, 1976; Deurloo et al., 1990). A strong income effect on tenure choice is therefore expected. Home-ownership is also associated with wealth; even though mortgages are widely available in the Netherlands, they are more easily obtained when one has some savings of one's own. Although wealth is not measured here, the unmeasured effect of wealth accumulation could, in the age groups under study, appear as a positive age effect.

Age can be viewed as an indicator not only of wealth accumulation but also of various other processes in the life course. Home-ownership requires a higher level of commitment than tenancy in the sense of long-term financial obligations: it can be viewed as a sign of 'settling down' (Mulder and Manting, 1994). Settling down is presumably avoided by young people just starting their housing, household and labour careers. Clark et al. (1994) conclude that home-ownership seems to require a certain stability, not only in income but also in family status. It can be hypothesized that, even when income level and household state are controlled for, an outlook on stability is more likely for the somewhat older people than the younger.

There is also evidence of the influence of household state on the choice between renting and buying. It has often been found that singles are not much inclined to buy a home (e.g. Kendig, 1984; Clark et al., 1994). Many singles will regard being single as a temporary phase and will be reluctant to invest in home-ownership prematurely. Couples and families are much more inclined to buy. This relationship is expected to be persistent after controlling for household income.

There is some evidence that couples pursue home-ownership before having children. The cost of rearing children competes with the cost of purchasing a home (Courgeau and Lelièvre, 1992). As Kendig (1984) puts it: "The capacity to buy is most usually achieved by young adults who combine two earnings in one household and save before beginning a family". Couples anticipating having children will have higher odds of buying, so that existing couples have higher odds than newly formed couples. In addition, a sense of stability (see above) is more likely among existing couples.

With regard to the effect of a second earner in the household on tenure choice, one can expect a positive influence on home-buying through the generation of extra income. But it is not immediately clear what one should expect from the effect of a second earner when income is controlled for. One could argue that, with two occupational careers within the household, there is more uncertainty about both partners still working in the same location, or remaining in work at all. Empirical evidence from the Netherlands shows that 50 per cent of all females living in two-earner households retreat from the labour force upon the event of having their first child and that 70 per cent of those remaining employed experience a substantial reduction in the income from paid employment (Klaus and Hooimeijer, 1993). Both the couple themselves and the bank providing the mortgage loan may anticipate future income loss caused by one partner exchanging paid work for the care of children. Consequently, either the couple, the bank, or both may be reluctant to take both incomes completely into account when calculating the monthly cost the couple can afford. Haurin and Gill (1987) argue that uncertainty of income streams affects the demand for owner-occupied housing. The inclination to invest in home-ownership 
would therefore be lower compared with the situation whereby the same income is earned by one earner because of an anticipated non-permanence of the income. On the other hand, research has shown that two-earner households have a lower propensity to move (Mulder, 1993). The selection effect of anticipating no future moves could therefore make them more inclined to buy.

The context displays a spatial and a temporal variation. The Netherlands shows a moderate spatial variation in housing markets. In the Netherlands as a whole, somewhat less than half of the housing stock consists of owner-occupied dwellings. Some local markets are, however, dominated by owner-occupied dwellings, others by rented housing. The larger cities in particular have a large share of rented accommodation. This difference in local housing markets, of course, influences the outcome of the tenure choice.

Table 1 Economic indicators, 1973-1989

\begin{tabular}{|c|c|c|c|c|c|c|c|}
\hline & $\begin{array}{r}1 \\
\text { GNP }\end{array}$ & $\begin{array}{r}2 \\
\text { Real } \\
\text { wages }\end{array}$ & $\begin{array}{r}3 \\
\text { Purchasing } \\
\text { power }\end{array}$ & $\begin{array}{r}4 \\
\text { Consump- } \\
\text { tion }\end{array}$ & $\begin{array}{r}5 \\
\text { Inflation }\end{array}$ & $\begin{array}{r}6 \\
\text { Mortgage } \\
\text { interest }\end{array}$ & $\begin{array}{r}7 \\
\text { Construc- } \\
\text { tion } \\
\text { owner- } \\
\text { occupied }\end{array}$ \\
\hline 1973 & 5.0 & 25.6 & & 3.0 & 8.0 & 8.0 & 59.8 \\
\hline 1974 & 4.1 & & & 1.9 & 9.6 & 9.6 & 64.2 \\
\hline 1975 & -.9 & 26.7 & & 2.5 & 10.2 & 9.3 & 56.4 \\
\hline 1976 & 5.2 & & & 4.8 & 8.8 & 8.8 & 52.4 \\
\hline 1977 & 2.4 & 27.1 & & 4.0 & 6.4 & 8.7 & 59.8 \\
\hline 1978 & 2.0 & & & 3.7 & 4.1 & 8.3 & 63.7 \\
\hline 1979 & 2.5 & 28.4 & & 2.3 & 4.2 & 9.1 & 55.8 \\
\hline 1980 & 1.0 & 27.7 & -1.6 & -.8 & 6.5 & 10.2 & 63.8 \\
\hline 1981 & -0.8 & 26.6 & -3.9 & -2.7 & 6.7 & 10.9 & 46.9 \\
\hline 1982 & -1.5 & 25.9 & -2.4 & -1.9 & 5.9 & 10.0 & 34.1 \\
\hline 1983 & 1.7 & 25.1 & -3.7 & .3 & 2.7 & 8.3 & 36.1 \\
\hline 1984 & 2.9 & 23.8 & -2.7 & .4 & 3.3 & 8.3 & 42.6 \\
\hline 1985 & 2.9 & 23.8 & 0.0 & 1.9 & 2.3 & 7.8 & 43.3 \\
\hline 1986 & 1.5 & 24.2 & 3.1 & 2.6 & .1 & 7.0 & 48.6 \\
\hline 1987 & 1.4 & & 1.9 & 3.3 & -.7 & 7.0 & 58.3 \\
\hline 1988 & 2.5 & & 1.1 & .2 & .7 & 6.9 & 66.9 \\
\hline 1989 & 4.4 & & 1.1 & 1.1 & 1.1 & 7.6 & 65.5 \\
\hline
\end{tabular}

1 Gross National Product, annual growth percentage. Source: CBS.

2 Average disposable income (thousands) in 1980 purchasing power. Source: CBS.

3 Average purchasing power, annual percentage change. Source: CBS.

4 Real private final consumption, annual growth percentage. Source: OECD.

5 Consumer price index, annual growth percentage. Source: OECD.

6 Average annual mortgage rate for new mortgages. Source: CBS.

7 Number of newly constructed owner-occupied dwellings (thousands). Source: CBS. 
In the period under study (1976-89) the temporal context changed considerably. This was true not only for opportunities and constraints; it was also true for the sociocultural domain (creating the context for the formation of individual preferences) and the composition of the population with regard to life course characteristics. Some indicators of the evolution of housing opportunities and economic constraints are given in Table 1.

The housing market in particular showed major changes in the 1970s and 1980s. The seventies were a boom market decade for owner-occupied dwellings. The ratio of housing cost to income of owner-occupiers decreased rapidly, indicating that the real disposable incomes of owner-occupiers rose faster than those of renters (Van Dongen et al., 1982). As a result of the developments in inflation and interest rates, mortgages and other loans were relatively affordable up to the end of the seventies. Home-ownership came within reach of a growing group of people, including young, starting households. In 1979, the market for owner-occupied housing collapsed. Van Dongen et al. (1982) put forward decrease in inflation, decrease in real income and rise of mortgage interest as reasons for the collapse. The year 1979 was the first of a number of years of rapidly falling prices (Kersloot and Dieleman, 1988; Janssen, 1992). Prices kept decreasing until 1982, remaining at a low level until 1985, when they started rising again. The eighties also showed decreasing mortgage interest rates and a recovery of new construction in the owner-occupied market.

The years 1980-82 were also a period in which unemployment skyrocketed and a decline in average real disposable income and consumption occurred. The crisis years were followed by a period of economic recovery lasting throughout the eighties. So, both housing market and economic conditions were unfavourable for starting home-ownership around 1980, to recover afterwards.

Existing evidence from Dutch data (Dieleman and Everaers, 1994) shows that the proportion of movers becoming home-owners developed consistently with economic and housing market evolution in the late seventies and throughout the eighties. Home-ownership was started less often in 1980-81 than before but gained a larger share later in the eighties. So, it is known that the aggregate outcome of tenure choices correlates with economic and housing market indicators in a predictable manner and that the correlations are strong.

There were major changes in the composition of the population in the period under study. Table 2 summarizes the dynamics in age composition in the seventies and eighties. In terms of age composition an upward effect on home-buying could be expected during the period 1977-1985, as the number of 30-39 year olds grew very rapidly in this period (1946 being the start of the post-war baby boom). However, the share of this age group in the total population aged 18-39 only rose from 37.5 per cent to 44 per cent between 1977 and 1985.

The changes in household structure have been more dramatic (Table 3). Among the total group the share of persons in two-parent families dropped from 49 per cent in 1977 to 36 per cent in 1989. The absolute numbers of families dropped. After controlling for age, the effect is even more pronounced, in particular among the people aged 25-29. The percentage of people living singly (including one-parent families) more than doubled over this period in each age group, representing an 
Table 2 Persons per age group (thousands), 1977-1989

\begin{tabular}{lrrrr}
\hline Age & Year & & & \\
& 1977 & 1981 & 1985 & 1989 \\
\hline $18-24$ & 1649.6 & 1697.9 & 1756.4 & 1733.3 \\
& $35.3 \%$ & $34.0 \%$ & $33.0 \%$ & $32.5 \%$ \\
$25-29$ & 1272.3 & 1156.1 & 1221.0 & 1264.0 \\
$30-39$ & $27.2 \%$ & $23.1 \%$ & $22.9 \%$ & $23.7 \%$ \\
& 1754.7 & 2143.6 & 2347.2 & 2331.9 \\
& $37.5 \%$ & $42.9 \%$ & $44.1 \%$ & $43.8 \%$ \\
\hline Total & 4677.2 & 4998.2 & 5325.2 & 5329.8 \\
\hline
\end{tabular}

Source: CBS Housing Demand Surveys (person-based weights).

Table 3 Persons per household state (thousands), 1977-1989

\begin{tabular}{lrrrr}
\hline \multirow{2}{*}{ Position } & Year & & & \\
& 1977 & 1981 & 1985 & 1989 \\
\hline With parents & 1163.7 & 1205.8 & 1352.1 & 1324.9 \\
Single & $24.9 \%$ & $24.1 \%$ & $25.4 \%$ & $24.9 \%$ \\
& 289.5 & 464.7 & 744.5 & 826.2 \\
Couples & $6.2 \%$ & $9.3 \%$ & $14.0 \%$ & $15.5 \%$ \\
& 836.3 & 965.5 & 991.4 & 1127.7 \\
Families & $17.9 \%$ & $19.3 \%$ & $18.6 \%$ & $21.2 \%$ \\
\multirow{2}{*}{ Other } & 2307.6 & 2187.6 & 2111.3 & 1931.5 \\
& $49.3 \%$ & $43.8 \%$ & $39.7 \%$ & $36.2 \%$ \\
& 79.5 & 174.0 & 125.3 & 118.9 \\
Total & $1.7 \%$ & $3.5 \%$ & $2.4 \%$ & $2.2 \%$ \\
\hline
\end{tabular}

Source: CBS Housing Demand Surveys (person-based weights).

increase of nearly half a million households. The expected effect is a decline in the percentage of first-time buyers, as singles are more prone to renting and families more prone to owning their residence.

Another compositional effect is shown in Table 4 and refers to the share of dual earners among people living as a couple in the age group 18-39. This share has risen dramatically both for couples without and with children. However, in 1989, having children still has a negative effect on the labour force participation of women in the Netherlands.

Figure 1 shows the development of real disposable household income during the period. The bars in the plot show the limits of the first and the third income quartile, the horizontal mark represents the median income. The figure shows that from 1977 to 1981 in particular middle incomes decreased (a lower median income 
Table 4 People in two-earner household, thousands and percentages of total group

\begin{tabular}{lrrrr}
\hline & Year & & & \\
& 1977 & 1981 & 1985 & 1989 \\
\hline Couples & 603.0 & 751.2 & 771.3 & 990.1 \\
& $72.1 \%$ & $77.8 \%$ & $77.8 \%$ & $87.8 \%$ \\
Families & 157.2 & 250.1 & 275.6 & 391.3 \\
& $18.8 \%$ & $25.9 \%$ & $27.8 \%$ & $34.7 \%$ \\
\hline Total & 760.2 & 1001.2 & 1046.9 & 1381.4 \\
\hline
\end{tabular}

Source: CBS Housing Demand Surveys (person-based weights).

with stable first and third quartile limits). In 1985 the total population suffered income losses of about 15 per cent compared with 1977. After 1985 the middle and higher-income groups seem to profit more from the economic recovery than the lower-income groups. The expected compositional effect is a low propensity to buy in 1985 in particular.

To conclude, existing evidence leads to separate bivariate hypotheses with respect to life course and context factors. These are summarized in Scheme 1.

Figure 1 Income distribution, 1977-89: median, first and third quartiles

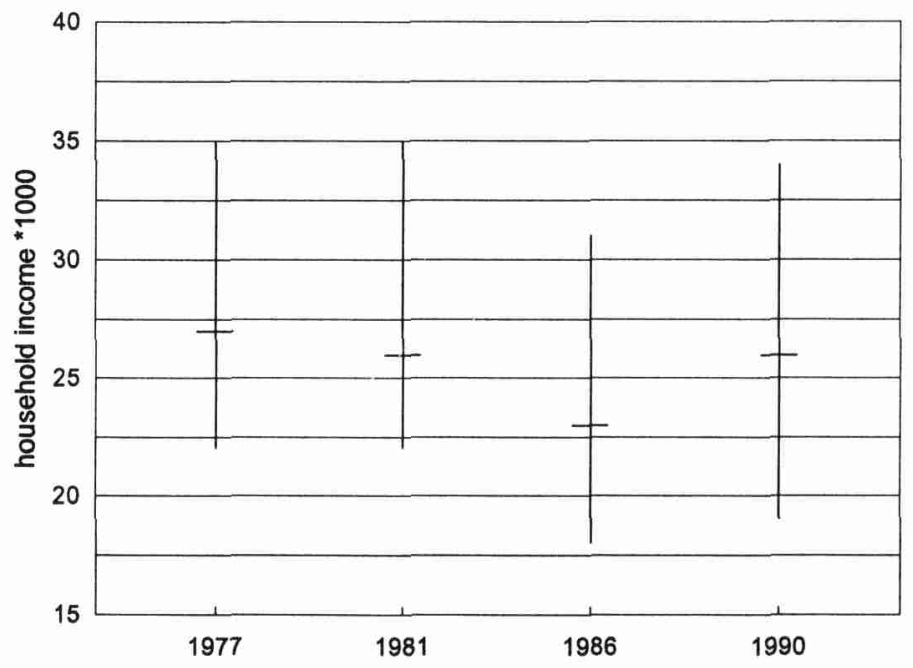


Scheme 1 Hypothesized effects of compositional and contextual change on total first-time home-buying

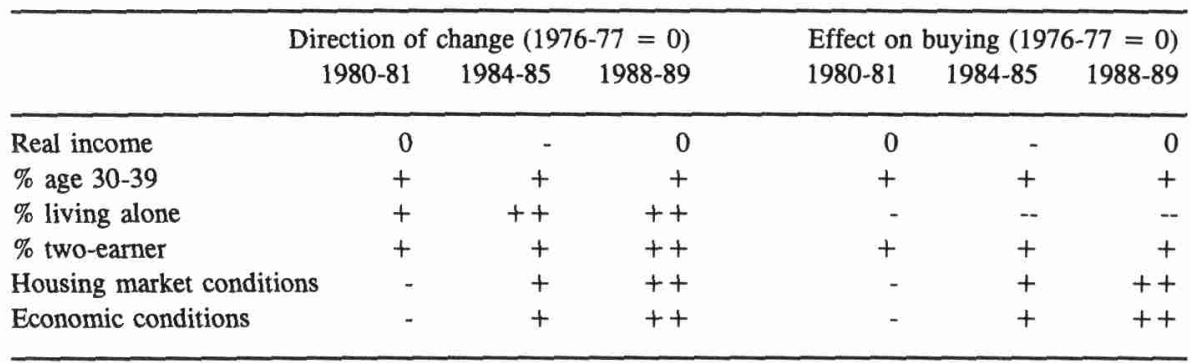

As can be seen from the scheme, the evolution of the percentage of first-time buyers is influenced by various trends. The demographic trend leads to a decreasing percentage due to the change in household composition, compensated to some extent by the rising share of two-earner couples and the rise in incomes after 1985. Improving housing market and economic conditions led to an increasing percentage after 1981 . In a multivariate analysis, compositional effects can be ruled out, isolating the effect of the context with more precision.

\section{Data and methods}

The data for this article were derived from the CBS Housing Demand Surveys (Woningbehoefte-onderzoeken or WBOs) conducted in 1977, 1981, 1985 and 1989. The WBOs are large-scale samples (about 55,000 respondents per WBO) taken from the Dutch population aged 18 and over not living in institutions. They contain information about current housing situations and recent moves, among other things.

The WBOs have developed into a major data source for a variety of studies of housing, residential mobility and migration in the Netherlands. An increasing number of studies analyse pooled samples from more than one WBO. Most of these studies use the 1981, 1985 and 1989 versions, leaving out the 1977 survey. Some reasons for leaving out 1977 are probably the substantial revisions of the questionnaire between 1977 and 1981; the annoyingly large partial non-response with regard to previous place of residence in 1977; and the lack of information about the previous household situation of movers in the 1977 survey. The latter two features of the 1977 version in particular severely hamper the identification of a population 'at risk' of moving. These drawbacks are bypassed here because only those respondents who move are included: destination choice is analysed rather than the 'risk' of moving. Household situation, for example, is not measured before the move but at the moment of moving.

In order to correct for selective non-response, CBS provides weighting factors which produce a post-stratification with respect to marital status, sex, age, family 
situation, and degree of urbanization. The weighting factors (person-based) were used in the cross-tabulations (Tables 2 through 5). Using case weights in an analysis has a disadvantage, however: the standard errors of the parameters are less accurate. This is why case weights were not used in the multivariate analyses where most of the stratifying variables were included.

Those respondents selected were aged 18-39 in the year of survey and moving from a dwelling they did not own. This includes people moving from their parental homes but not children who remained with their parents after the move. Households without income were excluded. The analyses pertain to the respondent's last move, but only if it was made in the year of survey or the year before (a period of 21 months approximately). For moves made still further back in time, the respondent's situation on the date of interview was thought to be no adequate proxy for the situation at the moment of the move. Tenure after this last move (renting or owning) is the dependent variable in the analyses.

Three age groups are distinguished: 18-24, 25-29 and 30-39. Household income has been measured as a continuous variable in thousands of guilders of real disposable income (taking 1977 as a basis and deflating later measurements).

Household state was measured directly after the move. Those forming a couple at the moment of moving ('synchronized' with moving, see Mulder and Wagner, 1993) are distinguished from the singles and the existing couples. This distinction permits comparing 'new' couples with those more likely to have achieved a stable family situation and to anticipate having children in the near future (see Section 2). Divorcing and separating movers are treated as single movers or couple-formers, depending on their household situation after the move. The number of income earners (one or two) is, of course, only considered for households consisting of more than one person; incomes earned by children in the household are not considered.

The local housing market situation is expressed in a variable denoting whether the moves end in one of the four large cities: Amsterdam, Rotterdam, The Hague and Utrecht. Changes through time are measured as a period variable, denoting the year of the survey and the year before (1976-77, 1980-81, 1984-85, and 1988-89). Measuring the complex of contextual variables in one period variable is a strategy also advocated by Deurloo et al. (1994). They point at the high intercorrelation between economic indicators generating periods very favourable or not favourable to a move to home-ownership.

The analyses were performed using logistic regression models for a two-value dependent variable. The logistic regression model estimates the effect of one unit change in the independent variable on the logarithm of the 'odds' (log-odds) that the dependent variable takes one value rather than the other when controlling for the effects of the other independent variables. Log-odds are not an easily interpretable quantity. Fortunately, the parameters yielded are readily re-calculated to indicate the effect on the odds themselves by taking their exponents. The odds are quite straightforwardly the ratio of two probabilities: the probability of being in one category of the dependent variable, divided by the probability of being in the other category $(\mathrm{P} / 1-\mathrm{P})$. The logistic regression model is formally specified as follows: 


$$
\log \frac{\lambda(X)}{1-\lambda(X)}=a+\sum_{k} b_{k} X_{k}
$$

where $\lambda(X)$ is the probability of owning the new dwelling for a given covariate vector $X=\left(X_{1}, \ldots, X_{K}\right) ; b_{k}, k=1, \ldots, K$ are parameters, and

$$
a=\log \frac{\lambda_{0}}{1-\lambda_{0}}
$$

which is the log-odds for the baseline group. For independent variables measured at the continuous level, the value zero is the reference (compare the intercept in an ordinary regression). For categorical variables, the baseline group is re-formulated as the group having the average of the log-odds between all categories in the variable. A positive $b$ parameter represents a positive effect on home-ownership compared with the average of the categories within the effect, whereas a negative parameter represents a negative effect.

\section{Renting or buying: bivariate results}

Before proceeding to the logistic regression analysis of tenure choice by moving non-owners, a first impression of the magnitude of the share of people engaged in the processes of moving and tenure change is given in Table 5.

Table 5 Changes in home-buying transactions of persons 18-39 years old, 19771989

\begin{tabular}{lrrrr}
\hline & Year & & & \\
& $1976 / 1977$ & $1980 / 1981$ & $1984 / 1985$ & $1988 / 1989$ \\
\hline$\%$ movers & 20.6 & 20.5 & 21.8 & 22.7 \\
Total & 24.8 & 26.1 & 27.6 & 28.3 \\
Non-owners & 8.3 & 6.5 & 6.9 & 8.9 \\
$\begin{array}{l}\text { Owners } \\
\text { Total persons*1000 }\end{array}$ & 4675.8 & 4997.5 & 5324.7 & 5329.1 \\
\% buyers among movers & & & & \\
Total & 35.4 & 30.6 & 28.7 & 35.1 \\
Non-owners & 30.5 & 26.2 & 25.2 & 30.6 \\
Owners & 79.2 & 74.9 & 64.6 & 70.1 \\
Total movers*1000 & 962.8 & 1026.5 & 1162.9 & 1207.6 \\
\hline Total buyers*1000 & 341.5 & 314.2 & 333.9 & 424.3 \\
\hline \% first-time among buyers & 77.4 & 77.9 & 80.2 & 77.2 \\
\hline
\end{tabular}

Source: CBS Housing Demand Surveys (person-based weights). 
The total mobility rate of the group 18-39 was higher in 1989 than in the late seventies. Within this age group, the non-owners show a consistently rising proportion of movers in each period of 21 months from 1977 to 1989. The owners, however, were certainly less inclined to move in $1980 / 1981$ and in $1984 / 1985$, the period of rapidly falling prices.

As can been seen from Table 5 , the change in the percentage of buyers among the moving non-owners aged 18-39 corroborates the hypothesis that it declined from the late seventies into the eighties and rose again during the eighties. Restoration of this percentage of first-time buyers among the movers to the level of the late seventies, however, did not occur until after 1985.

If homeowners move, they are inclined to stay in the owner-occupied sector, as the second part of Table 5 shows. This stresses the importance of studying tenure choice separately for distinct previous tenure statuses (see also Deurloo et al., 1987). Over time, however, the percentages sticking to their tenure slackened, only to recover after 1985. The increase in the number of transactions on the market for owner-occupied property in 1985 among 18-39 year olds is caused by a growing propensity to move and the rising numbers of $18-39$ year olds; a rise in the percentage of movers buying a dwelling only occurred after this year. As a result, the percentage of first-time buyers among the buyers rose (the bottom row of the table). As can be seen from this table, the total mobility rate of the non-owners did not decrease with the reduction in transactions in the owner-occupied sector (as opposed to the mobility rates of owners). This provides a clear indication that the decision to move among the non-owners is not dependent on tenure choice, as is assumed in this analysis (see Section 2).

Figure 2 shows the possible effect of the compositional change with respect to household structure. The average propensity to buy is indeed very low among single persons and high among the (more stable) couples. The change in household structure, shown in Section 3, had a negative effect on the total percentage of first-time buyers from 1977 to 1989 . The figure also illustrates that this temporal pattern in the percentage of first-time buyers is different for various household types. Single persons and newly formed couples exhibit very stable, slightly rising percentages. Couples and families with young children, being most prone to buy in the late seventies, show a large drop in this percentage in the beginning of the eighties. Restoration sets in as early as $\mathbf{1 9 8 5}$ for all families with children. The general pattern is one of postponement of the decision to buy among childless couples or those with young children, catching up later in life, when children have been born and/or become older.

This pattern of postponement of the decision to buy is more clear in the temporal variation among the various age groups in the analysis. Figure 3 shows a sharp drop in the percentage of first-time buyers in the age group 18-21 from 1977 up to and including 1985. This drop is also present among 22-24 year olds. Among the higher age groups the pattern is different. The percentage of first-time buyers in 1985 is equal to that of 1981 for the age group 25-29 and it is higher than in 1981 for the age group 30-39. Although postponement can only be assessed in a truly longitudinal 
Figure 2 Percentage of buyers among moving renters by household status, 1977-89

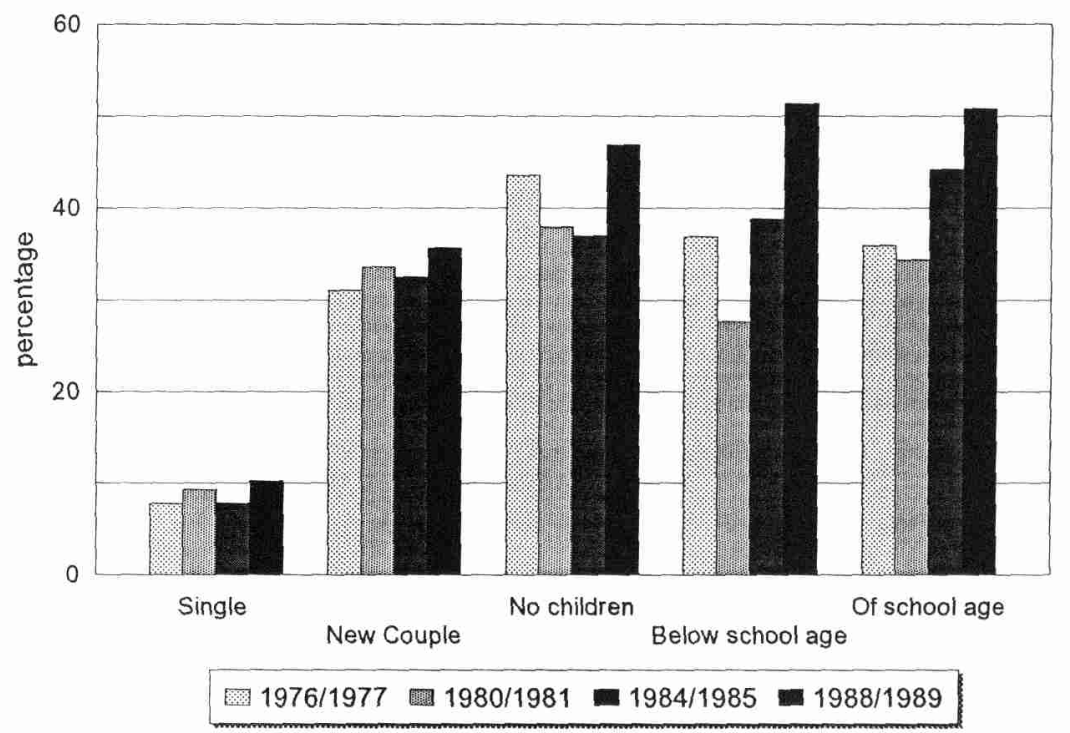

Figure 3 Percentage of buyers among moving renters by age, 1988-89

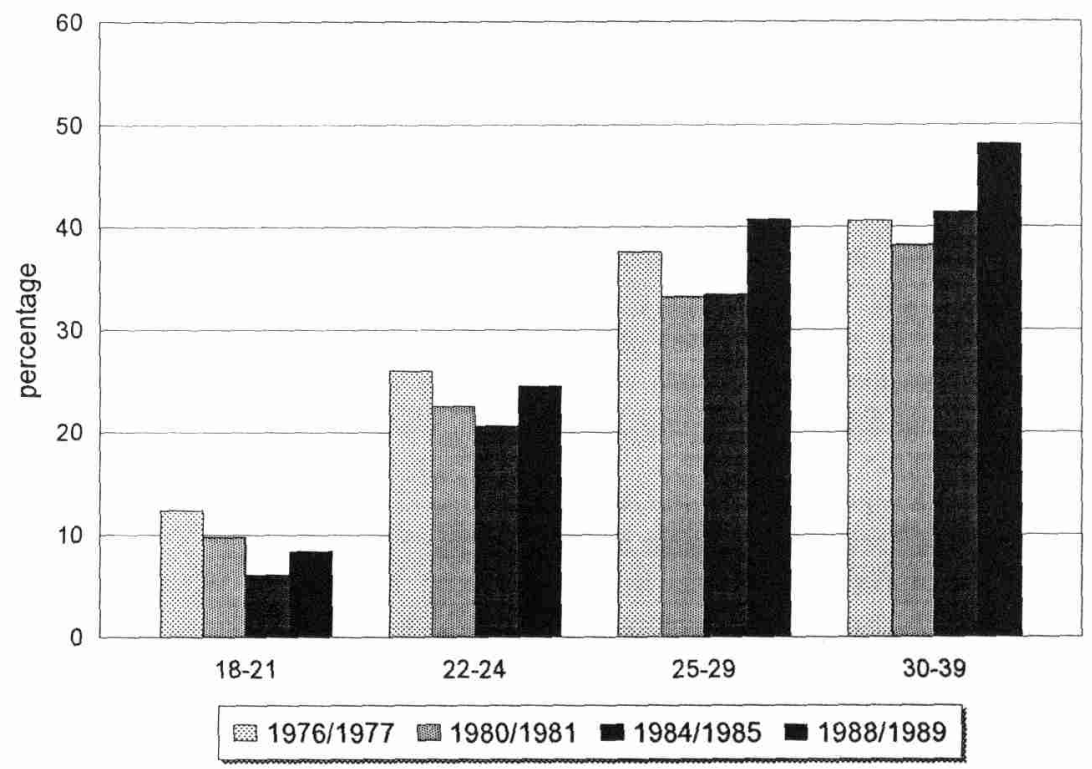


data set, the repeated cross-sections do indicate that the quick recovery of the propensity to buy among the higher age group is a result of people not buying at a younger age in the previous period.

The compositional change with respect to the age structure of the population of movers (growing numbers of 30-39 year olds) and the propensity change within age groups (highest among the 30-39 year olds) will together result in a positive effect on the percentage of first-time buyers over the periods.

With respect to the number of earners among the couples, the results are less pronounced than expected (Figure 4). Even though two-earner couples show higher percentages, the differences are not spectacular. This suggests that simply counting the number of earners in a household mixes the effect of household composition (singles versus couples) and number of incomes. Mixing these factors leads to erroneous conclusions with respect to the effect of the second income. To isolate the effect of the second income, controlling for other variables, the multivariate analysis should be restricted to couples only, an approach taken in the next section.

The relation between income and the percentage of first-time buyers is nearly linear and proves to be dynamic over time, as Figure 5 indicates. Middle-income groups (from 23 to 31 thousand guilders of disposable income in 1977 value) in particular appear to be sensitive to changing market conditions. For these groups, the percentage of buyers in 1981 is lower than in 1977. The lower-income groups

Figure 4 Percentage of buyers among moving couples/families, by number of earners, 1977-89

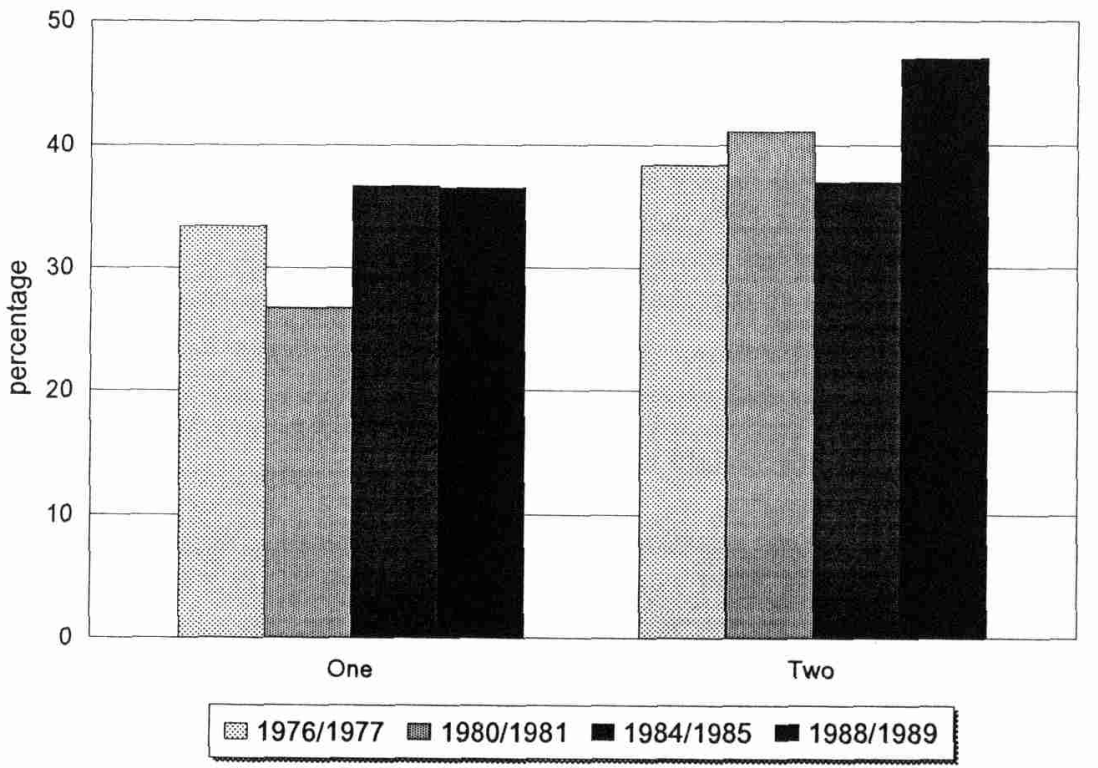


Figure 5 Percentage of buyers among movers, by household income, 1977-89

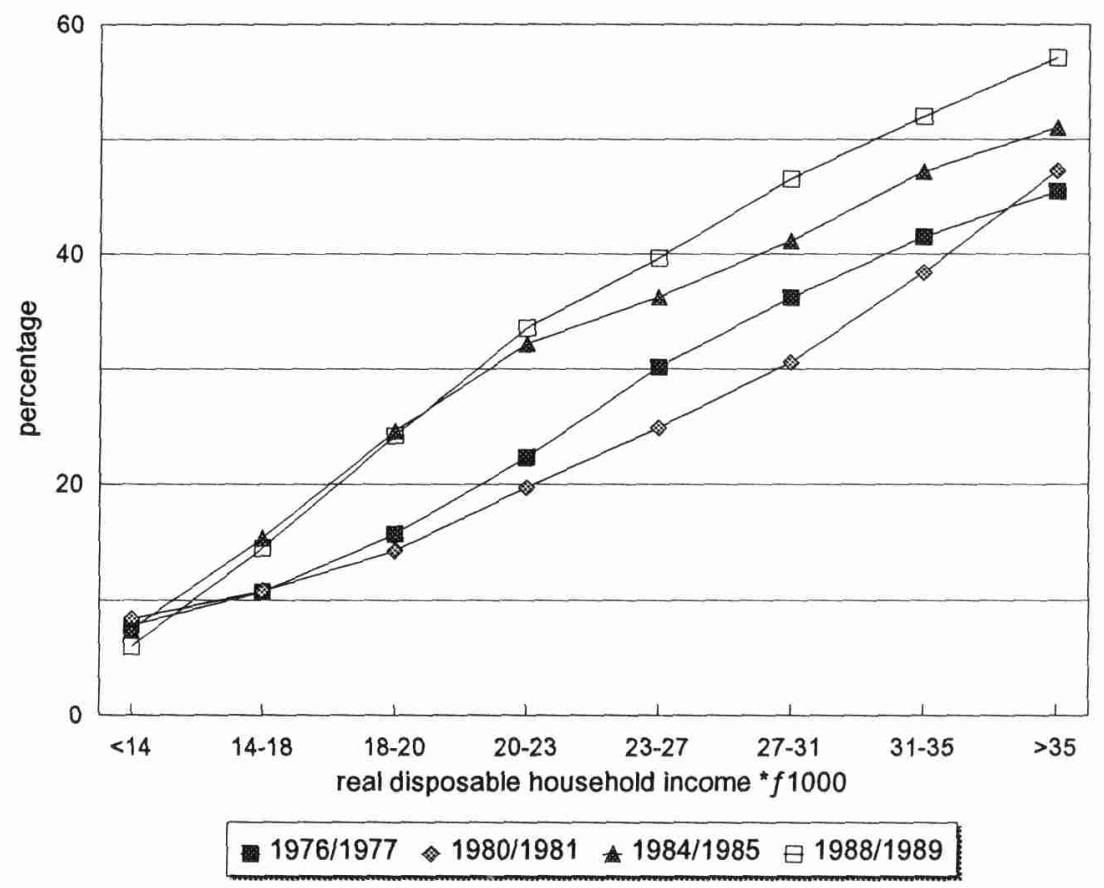

show a decreasing percentage over the total period. The percentage of buyers recovered most quickly (between 1981 and 1985) among the households with an income just below the median. The above-median incomes show a consistently growing percentage after 1981. Again, the pattern fits in with the idea of postporement of the decision to buy between 1977 and 1981. Following the train of thought presented by Kendig (1984), unfavourable market conditions with respect to entry into the owner-occupied sector will lead young households to postpone the decision. This allows them to accumulate more assets and enter the market at a later date.

\section{Renting or buying: multivariate results}

This section answers the basic question raised in this contribution: Which changes in propensity to buy show up after controlling for the changing distribution of the population with respect to life course factors that influence the decision to become a first-time home buyer? Logistic regression has been used to control for compositional effects. In Table 6, the results of two models are shown. The first model pertains to all households not previously owning a dwelling and moving during the 21 month period preceding the interview. The second model is based on a 
subset of this population: those living in more-person households. In both models, the dependent variable is the odds of buying rather than renting.

These models constitute a highly significant improvement over a base model containing only a constant (the significance of the difference between the Model -2 Log Likelihood and the initial -2 Log Likelihood is very near zero). By no means, however, do they approach a 'perfect' model predicting all individual choices in the right way (the significance of the Model -2 Log Likelihood is also very near zero). Such 'perfect' models are hardly ever obtained with large sample sizes. But it is also evident, from a substantive point of view, that the variables used in the model fall short of predicting individual outcomes of the tenure choice. Rather, they indicate deviations from the average odds of buying for subgroups in the population.

The results of the first model show a strong age effect in the same direction as the bivariate effect. For the youngest age group, the odds of buying -- averaged over the other categorical variables and for a household income of 20,000 guilders per year (1977 value) -- are estimated at $\exp (-2.72-0.48+20 * 0.06)$ or 0.18 . So, their probability of buying is estimated at $0.18 /(1+0.18)=0.15$. For the oldest age group, the odds are estimated at $\exp (0.36)$ or 1.43 times the average for all ages, and $1.43 / \exp (-0.48)$ or 2.3 times higher than for the youngest age group. The age effect is probably partly due to wealth accumulation, but it might also express a preference for the rental sector by the young, maintaining the flexibility to move if a (different) job or partner is found. As income is controlled for, the age effect will only to a limited extent reflect income rises common to the early phase of adult life (some shared covariance will exist).

There is a strong association with household type at the moment of the move. Single movers show by far the lowest incidence of owner-occupation. All other household types have odds at least twice as high. There is differentiation within the group of couples and families. In contrast to the bivariate finding, this differentiation no longer partly reflects income differences because income is controlled for. The newly formed couples are the least likely to buy a dwelling. They are at the beginning of their household careers, and postpone 'settling down'. Contrary to expectations, existing couples without children do not buy more frequently than households with young children. Households with young children do not move often (Mulder, 1993). But when they do, they make the transition to the owner-occupied sector relatively frequently. The odds of buying are somewhat lower again when the children are older. An interpretation of this phenomenon might be that there is a group of persistent renters who, if they did not buy early in their household career, are reluctant or unable to do so later.

Income is by far the strongest predictor of the decision to become a homeowner $(\mathrm{R}=0.24$ - not shown in the table). A rise in income by 10,000 guilders raises the $\log$-odds by $10 * 0.06=0.6$. Stated differently, the model predicts the odds of buying for households with a disposable income of 50,000 guilders to be four times greater than the odds for households having 25,000 guilders a year (median income).

The results of the second model for couples (Table 6) show the effect of a second earner in the household. When income and household type are controlled for, dualearner families have lower odds of buying than one-earner families. This means that, 
Table 6 Results of logistic regressions for all moving households and moreperson households

\begin{tabular}{|c|c|c|c|c|c|c|c|c|}
\hline & \multicolumn{4}{|c|}{ All moving households } & \multicolumn{4}{|c|}{ More-person households } \\
\hline \multicolumn{9}{|l|}{ Age } \\
\hline $18-24$ & -0.48 & & & & -0.37 & & & \\
\hline $25-29$ & 0.12 & & & & 0.10 & & & \\
\hline $30-39$ & 0.36 & & & & 0.27 & & & \\
\hline \multicolumn{9}{|l|}{ Household } \\
\hline Single & -0.83 & & & & - & & & \\
\hline New couple & 0.09 & & & & -0.14 & & & \\
\hline No children & 0.31 & & & & 0.12 & & & \\
\hline Young children & 0.32 & & & & 0.09 & & & \\
\hline School children & 0.11 & & & & -0.07 & & & \\
\hline Income & 0.06 & & & & 0.06 & & & \\
\hline \multicolumn{9}{|l|}{ No. of earners } \\
\hline One & - & & & & 0.08 & & & \\
\hline Two & - & & & & -0.08 & & & \\
\hline \multicolumn{9}{|l|}{ City } \\
\hline Large & -0.49 & & & & -0.55 & & & \\
\hline Other & 0.49 & & & & 0.55 & & & \\
\hline \multicolumn{9}{|l|}{ Period } \\
\hline 1977 & -0.22 & & & & -0.22 & & & \\
\hline 1981 & -0.20 & & & & -0.21 & & & \\
\hline 1985 & 0.12 & & & & 0.12 & & & \\
\hline 1989 & 0.30 & & & & 0.30 & & & \\
\hline Household & 1977 & 1981 & 1985 & 1989 & 1977 & 1981 & 1985 & 1989 \\
\hline Single & -0.12 & 0.16 & -0.08 & 0.04 & - & - & - & . \\
\hline New couple & 0.03 & 0.17 & 0.05 & -0.25 & 0.03 & 0.15 & 0.12 & -0.29 \\
\hline No children & 0.17 & 0.06 & -0.13 & -0.10 & 0.18 & 0.06 & -0.12 & -0.12 \\
\hline Young children & 0.07 & -0.30 & 0.03 & 0.20 & -0.01 & -0.20 & -0.05 & 0.26 \\
\hline School children & -0.14 & -0.09 & 0.13 & 0.11 & -0.20 & -0.00 & -0.05 & 0.15 \\
\hline Income level & 1977 & 1981 & 1985 & 1989 & 1977 & 1981 & 1985 & 1989 \\
\hline Lower 33\% & 0.15 & 0.14 & -0.07 & -0.22 & 0.07 & 0.28 & -0.18 & -0.17 \\
\hline Middle $33 \%$ & -0.01 & -0.18 & 0.08 & 0.12 & 0.01 & -0.19 & 0.07 & 0.11 \\
\hline Higher $33 \%$ & -0.14 & 0.05 & -0.01 & 0.10 & -0.07 & $-0,09$ & 0.11 & 0.06 \\
\hline Constant & -2.72 & & & & -2.61 & & & \\
\hline \multirow{3}{*}{\multicolumn{2}{|c|}{$\begin{array}{l}\text { Initial }-2 \text { Log Likelihood } \\
\text { Model }-2 \text { Log Likelihood } \\
\text { Improvement }\end{array}$}} & \multicolumn{3}{|l|}{23014} & \multicolumn{4}{|l|}{18540} \\
\hline & & 19172 & $(\mathrm{df}=187$ & $, P=.00)$ & 16609 & $(\mathrm{df}=14$ & $7, P=$ & \\
\hline & & 95 & $(\mathrm{df}=18$, & $=.00)$ & 124 & $(\mathrm{df}=18$ & $=.00)$ & \\
\hline
\end{tabular}

All parameters significant at 0.01 , except some of the parameters within interaction effects. Source: Analysis of CBS Housing Demand Surveys. 
given equal total household income, the odds of buying are lower when this income is earned by two persons than when it is earned by one. Two of the effects hypothesized above may be at work here: uncertainty whether both partners will remain working at the same location, and uncertainty about the permanence of the second income in light of a possible future exchange of paid work for the care of children.

It should be noted that, when income is not controlled for, two-earner couples have higher odds of buying than one-earner couples. The odds for two-earner couples are 1.74 times those for one-earner couples in a model with the same variables except income (results not shown).

A very strong negative effect on the odds of buying is exerted by the direction of the move: when the move ends in one of the four big cities, the odds are no more than $\exp (-0.49)$ or 0.61 of the average (Model 1). This results from the nature of the supply in the four cities compared with the rest of the housing market: both the stock and the new construction of owner-occupied dwellings are relatively restricted in the cities. It should be noted that movers with a strong preference for buying will often end up outside the city precisely because of this difference in supply. In those cases, the causation is not from the direction of the move to tenure type but the other way around. In a model including only families with children (results not shown), the effect of the direction of the move was even stronger $(b=-0.73, \exp (b)$ $=0.48$ ). This is probably caused by the specific characteristics of the owneroccupied market in the large cities. Owner-occupied dwellings in the cities are on average smaller and more often of the apartment type than those outside the cities. So, families staying in the city derive a relatively small advantage from buying rather than renting and might even view their stay in the city as less permanent.

The most interesting results, however, are at the bottom of the table, where period effects are shown. Both models control for compositional effects, although they differ in the way changes in household structure are controlled for. The first model controls for changes in household structure by including single households in the categorical variable 'household state'. The second model is restricted to moreperson households. The parameters indicating the period effect are identical in both models and contrast to the bivariate results. From a stepwise inclusion of variables (not shown) the expected period effect showed up in the first model: high odds in 1977; low odds in 1981 and 1985; and very high odds in 1989. Once other variables were included, household composition in particular, and to a lesser extent income, caused the signs to change, showing the pattern in Table 6: low odds in both 1977 and 1981; high odds in 1985 and 1989.

The conclusion that can be drawn from this is that the true contextual effects have been 'hidden' by changes in the composition of the population (in particular the sharp rise in the share of single households) and the drop in real incomes. Stated differently, the late seventies was a period in which a large number of young families lived in relative affluence, having a rather low propensity to buy a home. The middle eighties were characterized by lower incomes and a decreasing share of young families. The propensity to buy among these groups, however, was far greater. In the late eighties, buying a home became even more popular. Controlling 
for income, household and age composition, the odds of buying in 1989 were 1.68 times as high as in 1977.

The growing popularity of home-ownership has not evolved in the same way for each type of household. This is shown in the interaction effects at the bottom of Table 6. These parameters represent the deviation from what could be expected on the basis of the overall effects of household type and period. The lowest deviation of the baseline log-odds is estimated for the single households in $1977(-0.83+-0.22$ $+-0.12=-1.17)$. The highest deviation is estimated for families having young children in $1989(0.32+0.30+0.20=0.82)$. The odds for the latter group are more than seven times those for the first group.

The most surprising shift occurs between the couples without children and those with children. In 1977, couples without children were clearly more inclined to buy than those with young children $(0.17$ versus 0.07$)$. In 1989 , it is the other way around. Now couples having young children show a far higher propensity to buy $(0.20$ versus -0.10$)$. During the eighties, many women postponed the decision to become a mother. The decision to become a homeowner shifted even further to a time later in the life course. As many of the postponed births will occur during the nineties, an increased popularity of home-ownership might be expected in this era. It appears that having a child is increasingly becoming the point at which couples settle down.

It is interesting to note that the interaction between age and period was insignificant in Model $1(P=0.36)$. Apparently, the age differentiation of the period effect found in the previous section (Figure 3 ) is adequately 'explained' by controlling for household state and income.

With respect to income, the time trends show that the lower-income groups hardly participate in the increased interest in home-ownership. The negative interaction effect nearly offsets the overall growing propensity to buy for our total population. It was the middle-income groups that withdrew from the market in 1981 and re-entered again in the late eighties.

\section{Conclusions and discussion}

In this article, the joint influences of life course and context factors on tenure choice are studied. The data are derived from four CBS Housing Demand Surveys rather than the usual three. This results in a larger time frame, including the years before the 1980 collapse of the owner-occupied market rather than the 1980 s alone.

Jointly incorporating life course and context factors offers two major advantages. Firstly, it can be tested whether each of two sets of factors exert their own independent influence even when the other set is controlled for. And secondly, one can get an idea of the relative importance of the two sets of factors.

Both life course and context factors appeared to be significant even when measured in each other's presence. Income proved to have a strong resource effect on the odds of buying rather than renting. A positive age effect was found for the age groups under study (18-39). This was interpreted as an effect of wealth accu- 
mulation and a stronger tendency towards 'settling down' among the older age groups. As expected, a positive influence of the stability of households was found. Singles had lower odds of buying than people in any other household state. Newly formed couples had the lowest odds among couples and families. Contrary to expectations, couples with young children were no less inclined to buy than were stable couples presumably anticipating having children. Other findings might suggest a negative effect of the presence of children in the household. Those findings would partly reflect the probability of moving at all. Two-earner couples and families were found to buy less frequently than their one-earner counterparts after income was controlled for. The anticipated non-permanency of the second income was proposed as one of the explanations for this difference.

The spatial housing market context appeared to be of major importance for tenure choice. Moves ending in one of the four large cities were not likely to have an owner-occupied dwelling as their destination. The overall percentage of movers buying a home was found to change in the expected direction, indicating a decrease between 1976-77 and 1980-81 and an increase between the early 1980s and 1988-89. It was discovered, however, that after controlling for life course factors, there is clearly a consistently growing propensity to enter the owner-occupied sector.

The results gave no indication that either life course or context factors can be viewed as paramount in explaining tenure choice. Deurloo et al. (1994) conclude from an analysis of U.S. data that "household characteristics and changes in household characteristics seem to outweigh regional and especially time period effects on the propensity to move from renting to owning". This finding is not replicated for tenure choice in the Netherlands, however. Life course and context factors seemed to be of approximately the same importance in the period under study.

Our findings have important consequences for modelling future tenure choice evolution. The relative importance of individual and context factors for aggregate tenure choice in a future population depends upon the amount of change in population composition and the magnitude of economic and housing market change. Economic and housing market circumstances are commonly assumed to be rather volatile; they are said to behave in any predictable way in the very short run only. The findings in this contribution, however, showed far more consistency in the increase in popularity of home-ownership after controlling for household characteristics. In the same short run, the composition of the population with regard to life course characteristics is assumed to be rather stable. Nonetheless, this contribution showed a tremendous shift in household structure over a relatively short period. These compositional effects obscured the underlying structural change towards home-ownership.

Both micro approaches (paying attention to life course factors only and assuming stationarity in the propensity to buy for relatively homogeneous subgroups over time) and macro approaches (relating average percentages of home buyers to macroeconomic indicators) might render a distorted view of the real trends. Future research should aim at uncovering individual responses to changing market conditions by combining both micro and macro factors in one and the same analysis. 
Note

1 This article this partly based on Chapters 3 and 7 of Mulder (1993). A new feature of the analyses presented here is the inclusion of the 1977 Housing Demand Survey.

\section{References}

Clark, W.A.V., M.C. Deurloo and F.M. Dieleman (1994), "Tenure changes in the context of micro level family and macro level economic shifts", Urban Studies (31), no. 1, pp. 137-154.

Clark, W.A.V. and J.L. Onaka (1985), "An empirical test of a joint model of residential mobility and housing choice", Environment and Planning A (17), pp. 1-16.

Courgeau, D. and E. Lelièvre (1992), "Interrelations between first home-ownership, constitution of the family, and professional occupation in France", in J. Trussell, R. Hankinson and J. Tilton (eds.) Demographic applications of event history analysis. Oxford: Clarendon Press.

Deurloo, M.C., F.M. Dieleman and W.A.V. Clark (1987), "Tenure choice in the Dutch housing market", Environment and Planning A (19), pp. 763-781.

Deurloo, M.C., W.A.V. Clark and F.M. Dieleman (1990), "Choice of residential environment in the Randstad", Urban Studies (27), no. 3, pp. 335-351.

Deurloo, M.C., W.A.V. Clark and F.M. Dieleman (1994) "The move to housing ownership in temporal and regional contexts", Environment and Planning A (26), pp. 1659-1670.

Dieleman, F.M. and P.C.J. Everaers (1994), "From renting to owning: life course and housing market circumstances", Housing Studies (9), no. 1, pp. 11-25.

Doling, J. (1976), "The family life cycle and housing choice", Urban Studies (13), pp. 55-58.

Everaers, P. and F. Dieleman (1992), "Transitions between housing market segments: from rent to own, 1978-1989", Paper presented at the conference European Cities: growth or decline, The Hague, 13-16 April.

Haurin, D.R. and H.L. Gill (1987), "Effects of income variability on the demand for owner-occupied housing", Journal of Urban Economics (22), pp. 136-150.

Haurin, D.R., P.H. Hendershott and D. Kim (1993), "Living arrangements and homeownership decisions of American youth", Netherlands Journal of Housing and the Built Environment (8), no. 2, pp. 193-205.

Janssen, J. (1992), De prijsvorming van bestaande koopwoningen. Een analytisch onderzoek naar determinanten van prijzen en transacties van bestaande koopwoningen in vier Nederlandse gemeenten. Nijmegen: Katholieke Universiteit (thesis).

Kendig, H.L. (1984), "Housing careers, life cycle and residential mobility: implications for the housing market", Urban Studies (21), pp. 271-283. 
Kersloot, J.M. and F.M. Dieleman (1988), Van stagnatie tot herstel. De ontwikkeling van de markt van koopwoningen. Utrecht/The Hague: Instituut voor Ruimtelijk Onderzoek Rijksuniversiteit Utrecht/Nederlandse Vereniging van Bouwondernemers.

Klaus, J. and P. Hooimeijer (1993), "Inkomen en ouderschap: een longitudinale analyse", CBS-Supplement bij de Sociaal-economische Maandstatistiek, 1993/4, pp. 15-24.

Loikkanen, H.A. (1992), "Housing demand and tenure choice: evidence from Finland", Netherlands Journal of Housing and the Built Environment (7), no. 1, pp. 9-30.

Mulder, C.H. (1993), Migration Dynamics: a Life Course Approach, Amsterdam: Thesis Publishers/PDOD.

Mulder, C.H. and D. Manting (1994), "Strategies of nest-leavers: 'Settling down' versus flexibility", European Sociological Review (10), No. 2, pp. 155-172.

Mulder, C.H. and M. Wagner (1993), "Migration and marriage in the life course: a method for studying synchronized events", European Journal of Population (9), no. 1 , pp. 55-76.

Onaka, J. and W.A.V. Clark (1983), "A disaggregate model of residential mobility and housing choice", Geographical Analysis (15), pp. 287-304.

Rima, A. and L.J.G. van Wissen (1987), A Dynamic Model of Household Relocation, a Case Study for the Amsterdam Region, Amsterdam: Free University Press.

Speare, A., Jr., S. Goldstein and W.H. Frey (1975), Residential Mobility, Migration, and Metropolitan Change, Cambridge, MA.: Ballinger.

Struyk, R.J. and S. Marshall (1974), "The determinants of household home ownership", Urban Studies (11), pp. 289-99.

Van Dongen, H.J., G.G.J.M. Poeth and R.W. de Groot (1982), "Een beleidsperspectief voor de markt van koopwoningen (I)", Economisch Statistische Berichten (71), pp. 556-562. 